\title{
Abyssinia and Abyssinians of To-Day: Discussion
}

\section{Author(s): Gerald Campbell}

Source: The Geographical Journal, Vol. 60, No. 3 (Sep., 1922), pp. 192-194

Published by: geographicalj

Stable URL: http://www.jstor.org/stable/1781053

Accessed: 27-06-2016 08:39 UTC

\section{Your use of the JSTOR archive indicates your acceptance of the Terms \& Conditions of Use, available at}

http://about.jstor.org/terms

JSTOR is a not-for-profit service that helps scholars, researchers, and students discover, use, and build upon a wide range of content in a trusted digital archive. We use information technology and tools to increase productivity and facilitate new forms of scholarship. For more information about JSTOR, please contact support@jstor.org.

The Royal Geographical Society (with the Institute of British Geographers), Wiley are collaborating with JSTOR to digitize, preserve and extend access to The Geographical Journal 
are, apart from the Jibuti-Addis Railway, almost entirely lacking, but there is no reason why they should remain so. By extension of the railway from the coast; by linking up the country with the great central railway artery of Africa; by the formation of roads; and the utilization of the water powers of the rivers, there seems little reason why thisthe richest undeveloped district of Africa-should not be capable of contributing its quota to the wealth of the world.

But the difficulties in the way are great, as I have already pointed out ; it cannot do so alone and unaided, and it is jealous and suspiciousnot without reason - of foreign interference.

Nevertheless foreign assistance should, and indeed must, sooner or later be forthcoming in some form or another to help in the solution of the problem, and the form which this assistance should take, the manner in which it should be applied, is a matter which might well occupy usefully those who are responsible for, or interested in, the great question of African progress.

Mr. Gerald CAMPBell : I must congratulate the author on his interesting paper, and on the wonderful fund of knowledge he has acquired in Abyssinia. I feel a special regard towards him, because I think I was one of the first people he saw out there, and he was one of the last people I saw when I left Addis Ababa, after four and a half very interesting years, during which time Lij Yasu was deposed and the Mussulman-Christian war took place.

The paper deals with the present state of Abyssinia. I have not been there for two and a half years, but the present state is sure to be just like the past, from what I know of it. In reviews of this nature I feel that the chaotic state to which Lij Yasu reduced the country has not had its due. The chiefs of the different provinces had become used, under the reign of Menelik, to governing their provinces fairly well. They received orders from the Central Government in Addis Ababa, which they felt they had to obey. When Menelik died, and this boy $\mathrm{Lij}$ Yasu came to the throne, they felt that they ought to make allowances for a youthful ruler ; but when they were ordered to the capital and, after travelling several weeks to get there, found the ruler had gone out several miles into the bush-he was one of those internal navigators who like to have a wife in every port-or, after sitting up all night, had gone to sleep during the day, and they were kept outside the palace with their enormous retinues for many hours, they degenerated, and the country became chaotic. He was succeeded by Zauditu, but not in the approved manner, because an Abyssinian ruler, to be worth his or her salt, must fight his way to the throne, and Zauditu was appointed without the firing of a shot. It was not until some weeks later that fighting took place, and that was not so much to put her on the throne, or to keep her on the throne, as a war of Christians for their religion against the Mussulman. Further, that was not altogether an Abyssinian affair; it was partly an off-shoot of the European war. It is true that Lij Yasu fought to regain the throne, or rather he remained in a convenient place for running away, while his father did the fighting and was captured, but I was credibly informed that he had at this time a letter from the Kaiser in his pocket stating what he would do for him if he proclaimed for Germany. As all the frontiers were occupied by Mussulmans, I do not know how many troops we should not 
have had to divert from the fronts to keep Somaliland, the Sudan, and possibly Egypt had the Christians lost the battle.

There was also, when Zaditu came to the throne, a prejudice against a woman, and in the proclamation which she made at the time of her coronation she made graceful allusion to Queen Victoria as being, not only a short woman -and Zauditu herself was not tall-but a great woman like she hoped to be.

Having a woman on the throne, all the chiefs hoped to be able to use her for their own particular and personal benefit. They hoped to do the same with Ras Tafari. When they found he was going to take a part in the administration, they said to him, "Crown princes never do any work"; but he resented this allusion to "Little Willie" and stuck to his guns. The Christian-Mussulman war naturally produced chaos in the country. I believe there has also been some chaos in Europe since the war. The Empress was wise enough to see this, and made an unkind remark one day, when I told her the state of the country was chaotic, and the sooner it ceased to be so the better it would be for everybody concerned. She said, "Yes, it is quite true; God is punishing most of the nations of the world by giving them bad governments, and I do not think that $\mathrm{He}$ is punishing Abyssinia more than a good many others."

The author has told you a good deal as to the mentality of the Abyssinians. They are obstructionists by nature, and suspicious of themselves and every one else, and especially of foreigners. To give an example of this, at one time they had the idea of using the natural resources of their country to make their own cartridges and ammunition. There happened to be an Australian prospector in the country, and they thought they would send him to where copper had been reported, and get him to say whether it would be good enough for them to use at the Government cartridge factory at the capital. They gave him a passport to proceed to this place without hindrance. He got there and started digging, but they stopped him at once and said, "You are allowed to proceed here without hindrance, but you are not allowed to dig." A message was sent back to the capital, which was a month away, asking for permission for him to dig, and the authorities took about a month to think it over, but at last granted it. He commenced to dig and saw some promising specimens, which he put in his pocket to smelt in his tent. He was immediately arrested and taken for a several months' journey round the north, because it was said that he was allowed to dig but not to take anything away.

The Abyssinians cannot see beyond their noses, because they never travel beyond their noses. During the war I tried to get them to export cattle, and told them of the big fortune they could make by exporting some of their large stocks of cattle, but they said, "Every beast exported is a beast lost to the country." I told them it would encourage breeding, but they replied that they did not think that wanted to be encouraged.

As the author has said, they do not always get very good specimens of Europeans ; nor do such Europeans set them good examples by their behaviour, or by what they have sent out to them. Thus I remember, at a time when the caravan routes were more than usually insecure, we tried to impress on them that such things were incompatible with modern civilization. We never thought of the "movies," but sure enough, shortly afterwards along came the first cinematograph -twenty-four blood-curdling films, "The Mysteries of New York."

I am not trying to excuse the Abyssinians; the state of affairs is horrible ; but I am trying to explain in some degree how the present situation has come about since Menelik's death. I believe that the Empress, Ras Tafari, and 


\section{I94 ABYSSINIA AND ABYSSINIANS OF TO-DAY-DISCUSSION}

some of the chiefs would do something if they were given a chance. Otherwise I do not know what the future will be. Perhaps they will have to await the fulfilment of the prophecy which was made about the Ark of the Covenant, which was believed to be sealed up in the sacred city of Axum. It was said that the original Menelik, the son of Solomon and the Queen of Sheba, went to Jerusalem to stop with his father. When he got tired of staying there Solomon would not let him go back, and he therefore made his escape. He was just being overtaken by Solomor's cavalry, when he caught up with a procession which was conveying the Ark of the Covenant to some place near Gaza. As the cavalry were overtaking him, suddenly the whole procession, himself, and the Ark of the Covenant, were swallowed by the earth and fell into an underground passage which led them under the Red Sea to the sacred city of Axum in the north of Abyssinia. The stone which guarded the exit turned back just before the Ark went through, and the Ark is, therefore, still walled up in the passage, and the man who can unroll that stone from the inside will be the finest ruler that Abyssinia has ever had. The Empress and Ras Tafari are up against a wall of ignorant prejudice; joined to an arrogant feeling that Abyssinia's civilization is older and better than most others, anda Moslem sentiment in a Christian breast-why tire yourself out striving to kick goals, when you never even said you wanted to play?

The PRESIJENT: Mr. Rey has given us a most fascinating account of Abyssinia, and the reason why it has been so good is that he has evidently acquired a real love for the country. $\mathrm{He}$ is so taken with it that he is going back again this year, and he would like to go back as often as he could. For that reason he has been able to enter into the real spirit of the country and form an understanding of the character of its inhabitants, and as a result we have had the extraordinarily interesting and valuable lecture to which we have listened.

Of course, in Abyssinia, as in so many other countries, one is up against the most difficult problem of how to preserve the respect and independence of the people, and at the same time secure their progress. I am certain that we British people would much rather secure the progress of other countries while preserving their independence than by using force against them. That is always an exceptionally difficult problem. I quite agree with the lecturer that the right way is by the country being given the assistance of Europeans. The further difficulty arises, however, that a country like Abyssinia, like the Royal Geographical Society, should only have the best, and unfortunately it is not very easy to get the best Englishmen, or the best Europeans of any kind, to go out to a country like Abyssinia into the service of a Government of the nature which the author has described, and devote the best part of their life to that. Service in a country like Abyssinia is probably very precarious, and there is always the very serious difficulty that if you have a good man out there and he gives advice, it is not taken. There the problem is, however. We have got to influence countries of this kind while respecting their independence as far as we possibly can. I think really what we shall have to do in future is to regard their progress not so much from the standpoint of material progress, but start at the other end and take them on the highest side, on the side of culture, and I think we shall get better results, and material progress will follow. I know that you would like me to propose a very hearty vote of thanks to the author for his exceedingly interesting lecture. 